Беларускі дзяржаўны эканамічны ўніверсітэт Факультэт міжнародных бізнес-камунікацый Кафедра беларускай і рускай моў tel.: +375172098894 e-mail: o_gubskaya@mail.ru

ORCID ID: https://orcid.org/0000-0002-8066-4207

\title{
Дакументальны факт як вобраз мастацкай літаратуры
}

Ключавыя словы: дакументальны факт, мастацкая літаратура, топас, нон-фікшн, літаратура факта

Як бы імкліва не развівалася сучасная літаратура, літаратуразнаўства XXI стагоддзя ўсё ройна будзе мець патрэбу ў пераасэнсаванні класічных твораў з пазіцыі сучаснасці, неабходнасць у новым ракурсе прачытаць гістарычныя факты ў хрэстаматыйных тэкстах, засяродзіцца на аналізе спосабаў выяўлення светапоглядных прыкмет пісьменніка ў прапанаваным чытачу мастацкім творы. Як адзначае Я. Гарадніцкі: "Перад літаратуразнаўчай навукай адкрываюцца сёння значныя перспектывы, адной з істотнейшых з якіх з'яўляецца магчымасць выяўлення спалучанасці светапогляду і мастацкага выражэння на ўзройні асэнсавання функцыянальнай ролі у у мастацкім дыскурсе ӱніверсальных катэгорый, вобразаў-архетыпаў, структурных адметнасцей твора. Пад гэтым вуглом гледжання важнейшай задачай літаратуразнаўчай навукі на сучасным этапе з'яўляецца распрацоўка метадалогіі вызначэння светапогладных асной літаратурнай творчасці ў іх мастацкім выражэнні, мастацкай і структурнай увасобленасці" [Гарадніцкі 2018, 54].

Паралельна з гэтым хочацца падкрэсліць, што ў сённяшнім літаратуразнаўстве ўзрасла цікавасць да літаратуры нон-фікшн, літара- 
туры факта, эга-дакумента, літаратуры чалавечага дакумента. Цікавасць шматбаковая: з аднаго боку, да факта як сюжэтаўтваральнага элемента; з другога боку, як да катэгорыі, якая ўплывае на структурную адметнасць твора; да катэгорыі, якая, атрымаўшы новае цэласнае значэнне, становіцца з'явай мастацкага тэксту, сродкам мастацкага выражэння аўтарскага светапогляду.

Задача дадзенага артыкула, вызначыць функцыянальную ролю факта $\breve{y}$ мастацкім дыскурсе, створаным класікам беларускай літаратуры Максімам Гарэцкім.

Феномен факта $\ddot{y}$ тым, што праз прызму ўспрыняцця творцы ён можа трансфармавацца ў факт мастацкі - "дакументальны факт, які атрымаў самастойнае эстэтычнае значэнне, г. зн., стаў гатовым вобразам. Адна з яго прыкмет - унутраная невычэрпнасць» [Местергази 2007, 42]. Але ў гэтым няма вялікага фокуса. Уся цікавасць у іншым: якія аспекты дакументальнага ці гістарычнага факта ў той ці іншы момант становяцца аб’ектам аўтарскай увагі, як яны пераасэнсоўваюцца і праз якія мастацкія сродкі транслююцца.

Па сутнасці, феномен факта, уключанага $\ddot{y}$ тэкст, выяўляецца $\ddot{y}$ тым, што ён функцыянуе як мастацкі вобраз, тым самым пашыраючы творчыя магчымасці пісьменніка. Ён адкрывае перад намі новую з'яву: пісьменніцкае пераасэнсаванне рэчаіснасці пры канкрэтных гістарычных, палітычных і сацыяльных умовах. Прадэмантструем гэта на прыкладзе.

Хваля ӱвагі да дакументалізму Гарэцкага ӱзнікла пасля атрымання Святланай Алексіевіч Нобелеўскай прэміі па літаратуры. У артыкуле Станаўленне дакументальна-мастацкага жанру ў журналістыць Святлань Алексіевіч Л. Сінькова адзначае: "У беларускай літаратуры самадастатковыя факты ӱ ролі мастацкіх вобразаў з'явіліся ўжо у першай трэці ХХ стагоддзя, бо, мусіць, ні адна бяда не абмінула Беларусь. Прыкладам можа служыць творчасць Максіма Гарэцкага, рэпрэсаванага і расстралянага ў 1938 г., вымушанага ствараць ва ўмовах высылкі сваю "Камаройскую хроніку" (гісторыю роднай вёскі Малой Багацькайкі, усёй Беларусі) не як традыцыйна мастацкі, спецыфічна цэласны тэкст, а як "чарнавое" пералічэнне фактаў, звязаных перш за ўсё канцэптуальна, а не стылёва" [Синькова, Басова, 2009].

Пры гэтым хочацца адзначыць, што ўзоры такога дыскурсу ў творчасці Гарэцкага праяўляліся ўжо з першых старонак яго тэкстаў. Магчыма, не так відавочна, як у дзённікавых нататках Ha імперыляістылнай вайне, Камароўскай хроніць ці рамане Віленскія камунарь (даследаванню ролі факта ў рамане прысвечана кніга Kласіка XX cma- 
годдзя: прыхаваныя таямнічы рамана "Віленскія камунары" М. Гарэчкага [Губская 2016]), але уусё роўна адчувальна. Можна сказаць, што творчы старт пісьменніка Гарэцкага - гэта крок ад факта да вобраза, ускладнены задачай не толькі эстэтычнага, але найперш духойнага характару. Зыходзячы з гэтага, важна зразумець: як, пры наяўнасці факта, арганізаваны аповедны пачатак твора? Якія прыкметы эстэтычнай арганізацыі тэкста? Іншымі словамі, наша задача адказаць на пытанне: як факт упісваецца Максімам Гарэцкім у фармат мастацкага твора, як факт рэальны ператвараецца ў вобраз і факт мастацкі? I пачнем мы з апавяданняў асветніцкага перыяду, які бярэ пачатак ад 1912 года. Наша даследаванне будзе грунтавацца на супастаўленні публіцыстычнага артыкула пісьменніка і мастацкага твора, напісаных прыблізна ў адзін і той жа час.

Агульнавядома, што ў якасці аўтара (карэспандэнта) газеты Наша ніва Гарэцкі пачаў выступаць з 13 (26) верасня 1912 года. Яго матэрыялы выходзілі ў пастаяннай рубрыцы 3 Беларусі $i$ Літвы і даносілі весткі з Горак. У маім артыкуле Нашаніўская дзейнасиь Максіма Гарэчкага: ад карэспандэнта да пісьменніка для ілюстрацыі актыўнасці супрацойніцтва пісьменніка з Нашай нівай прыводзіцца табліца, з якой дакладна бачна, як газетны артыкул плаўна перацякаў у літаратурны твор. На першы погляд гэта звычайная храналагічная інфармацыя, якая не павінна выклікаць асаблівай цікавасці. Але падобнае меркаванне зменіцца адразу пасля прачытання згаданага матэрыялу. Там адзначаецца, што пасля публікацый М. Гарэцкім у Нашай ніве артыкулаў Таварыство иьвярозасьиі, Не глядзелі-б вочьи (М. Б.) (№ 6 ад 7.02.1913) на працягу двух нумарой друкаваўся кароткі жалобны абразок Ampута (псеўданім "Максім Беларус", № 8 ад 20.02.1913 і № 9 ад 01.03.1913). I гэта не выпадковая заўвага.

Так, у артыкуле Не глядзелі б вочь Гарэцкі-журналіст распавядае

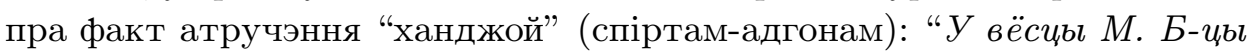
(Мсиіслаўскаго пав. Магілёўск. губ.) жаніў Пятрок Сілачонак свайго сына Ляксея. К свадзбі прывёз яму швагар ажно дзьве чвериі спірту - адгону ("ханджь", я кажуць у нас), частаваць гасьцей, "каб бывалі часцей". I ўжо нашто ласунь да гарэлкі нашь старыкі, але піџь гэта смярдзючае зельля неяк пасароміліся, иі можэ пабаяліся, каб не захварэиь. ... I ўсе-ткі, ліха-ж дало, на другі дзень бабу, Раманіху Лёксу, падпаілі гэтым адгонам ды так, што чуць жывую дамой занясьлі. Чуиь адратавалі, а то пайшла-б без парь на гай за выпіўку, кінуўшы мальх дзетак" [Наша ніва 1912]. А зараз звернемся да жалобнага абразка Ampyma. Сама назва адсылае нас да вышэйзгаданага 
нашаніўскага артыкула. Пры гэтым відавочна, што Гарэцкі-публіцыст і Гарэцкі-пісьменнік карыстаюцца рознымі творчымі прыёмамі, што дае нам магчымасць паразважаць над тым, як факт рэальны ператвараецца $\ddot{\mathrm{y}}$ факт мастацкі.

Пачнем з назвы - Ampута. Відавочна, што свежыя журналісцкія ўражанні знайшлі адбітак ў лаканічным загалоўку, які у кантэксце мастацкага твора выглядае метафарычна. Калі у артыкуле аўтар распавядае пра канкрэтную атруту, то у у абразку паняцце "атрута" ад фактычнай з'явы пашыраецца да метафары: атрута - гарэлка, атрута - чалавек, які “з'ядае” сваю жонку і дзяцей. Далей звернемся да імёнаў: ключавая постаць артыкула "Не глядзелі-б вочы" Раманіха, герой абразка - Раман. Зразумела, што пісьменнік не жадаў дубліраваць журналісцкі матэрыял, а карыстаўся ім толькі як ідэястваральным, таму змяніу "пол" персанажу, пры гэтым, не жадаючы цалкам аддаляцца ад факта, пакінуў імя. Ёсць такой метамарфозе і яшчэ адно тлумачэнне: задача нататкі - адчуць інфармацыйную нагоду, імгненна стварыць панараму падзеі (з прычыны фармату журналісцкага тэксту), прывесці да высновы-маралі - паказаць чытачу праблему, выклікаць пачуццё агіды да пьянства. I зроблена гэта, як бачым, без глыбокай драматызацыі сюжэту, больш карыкатурна, яскрава і праз антытэзу, якая, дарэчы вельмі ўдала вырысавалася ў Гарэцкага: мужчыны пабаяліся піць "ханджу", а Раманіха пагадзілася. Ды і ўвогуле, ці не карыкатурна $\ddot{y}$ прынцыпе выглядае пьяная жанчына! Тут трагічнае хаваецца за камічным.

У драматычным абразку Атрута Гарэцкі карыстаецца зусім іншымі прыёмамі, ды і задачу ставіць больш сур'ёзную. Твор - суцэльная драматызацыя сітуацыі. Ад факта застаецца толькі імя персанажа і сітуацыйная "атрута" - ніякага сарказму, карыкатурнасці і намёку на весялосць тут няма. Калі газетны артыкул пачынаўся вяселлем, то абразок (па прынцыпе кантрасту) - перадсмяротнай хваробай. Канешне, ёсць у творы месца і манеткам (якія звычайна дараць маладым), і кветачкам, але адыгрываюць яны у у творы асаблівую сімвалічную ролю. «"А у мяне грош! А у у мяне грош!" - радасна крычаў Косцік. “Ды не: гэта ў яго пяць, ажно вун, капеек; гэта, гэта... А у у мяне вун што, краскі! На табе, мама!" »- казала Аўдулька хворай маці, якая узжо не магла ўзняцца з ложка" [Гарэцкі 1985, 188]. У гэтай сцэне Гарэцкі, нягледзячы на тое, што яшчэ пачатковец у літаратуры, праяўляе сябе майстрам драматызацы: ён умее разгледзець у прадмеце двухбаковасць, палярнасць значэння і скарыстацца гэтай шматзначнасцю імгненна, як фокуснік, у адной сцэне. Дзяўчынка нясе любай матулі кветкі на 
радасць, а маці, адчуваючы свой стан, "выварочвае" гэты тэатральны атрыбут на свой лад: "Будзеш мне на могілку кветачак прыносіць... На радаўніцу з яечкам прыйдзі хрыстосавацца" [Гарэцкі 1985, 188]. Дарэчы, мае месца $\ddot{y}$ творы і тэма вяселля, што для артыкула стала падзеястваральнай, толькі ізной-такі, скарыстана яна з супрацьлеглым сэнсам, праз матыў сну Ганны: «Што я сніла сяння? Быццам нябожчыца мама, такая светлая, ясная, у беленькай світачцы, прыйшла к нам і да таго ж жаласна і сумна кажыць мне: "Ганначка, - кажэ, - галубка, чаго ты так счарнела ды высахла, выпятрыла ўся? Рыхтуйся, кажэ, - бо табе ж пад вянец пара, заждалася я цябе..."» [Гарэцкі 1985, 188]. Зараз вернемся да манетак, што дзеткі атрымалі як узнагароду ад каморніка на бублікі. Зноў пісьменнік прапускае "тэатральны атрыбут" праз кантрастнае светабачанне: манеткі, атрыманыя на радасць дзецям, прыносяць смерць самаму малодшаму Яначку. Вось як Гарэцкі стварае гэтую сітуацыю: Раман "падскочыў да бацькі і рвануў з рук грошы і маланкай пабег за дзверы; Яначка скаўзануў з дзедавай рукі і грукнуўся галоўкай аб падлогу" [Гарэцкі 1985, 192]. Маці, якая бачыла ўсё, памірае следам. Дзедавымі словамі: "Кара божая!" заканчваецца драматычны абразок Атрута.

Падкрэслім яшчэ раз, што гэты твор напісаны пасля выхаду артыкула Не глядзелі-б вочьl, і становіцца відавочным, што тэма пьянства настолькі хвалявала пісьменніка, што ён не мог спыніцца на крытычным рэпартажы фельетоннай танальнасці і напісаў драматычны абразок, наскрозь прасякнуты плачам, горам і пахам "атруты". I калі у артыкуле Гарэцкі спрабуе адлюстраваць з'яву аб'ектыўна, даючы магчымасць выказацца нават жонцы прадаўца гарэлкі: "А мне што? Хто ня хочыць, тэй ня пьець. А я, балазе, на беднасць сваю зараблю...бывае іншы святы дзень і на паўрубельчка", то у мастацкім творы, нягледзячы на тое, што Раман таксама спрабуе апраўдвацца, вырашае пытанне адназначна - пьянства гэта атрута, якая з'ядае жыцці людзей.

Якую выснову можна зрабіць з вышэйпрыведзенага аналізу твораў? Відавочна, што М. Гарэцкі сумяшчаў публіцыстыку з заняткам літаратурнай творчасцю, і гэта абсалютна лагічна: назіраючы за праявамі рэчаіснасці, пісьменнік знаходзіў сюжэты для сваіх апавяданняў; рэалізойваў пастаўленую перад «нашаніўцамі» задачу азнаямлення чытачоў з літаратурнымі навінкамі на беларускай мове, i, нарэшце, выкарыстойваў газету як пляцойку для выказвання сваёј грамадзянскай пазіцы. Дакументальны факт Гарэцкі выкарыстоўвае як аснову для ідэі мастацкага твора. Пры гэтым ён не капіруе фактычныя пад- 
зеі, а па-мастацку іх апрацойвае, пакідаючы сувязныя ніці паміж матэрыяламі. Пісьменнік па-рознаму падыходзіць да падачы "аўтараскага мэсэджу": у публіцыстычным артыкуле Гарэцкі стварае аб'ектыўную карціну рэчаіснасці і пакідае права выбару (у нашым выпадку "піць ці не піць") чытачу, а ад сябе дадае маленькую рэмарку: "Вось якая тут "чудасія". Не глядзелі-б вочы". У мастацкім творы мы зусім не чуем адкрыты аўтарскі голас, толькі можам меркаваць, што фраза "Кара божая!", сказаная дзедам, вельмі блізкая і пісьменніку Гарэцкаму. Сілу аўтарскага голасу мы адчуваем праз энергетыку драматычнага напружання калізіі, праз па-мастацку зафіксаваныя "кантрасныя фарбы" антытэзы, якія падкрэсліваюць дыяпазон аўтарскіх эмоцый. Публіцыстычныя артыкулы, у якіх зафіксаваны рэальны жыццёвы факт, даюць магчымасць прасачыць за тым, як пісьменнік Гарэцкі гэты факт апрацоўваў. Менавіта з аналізу публіцыстычных артыкулаў варта пачынаць гаворку аб месцы факта ў мастацкай творчасці Максіма Гарэцкага, бо факт як аснова журналісцкага матэрыялу стаў тым інструментам, які выточваў мастацкую манеру пісьма сённяшняга класіка беларускай літаратуры.

Працу з фактам, як сюжэтаўтваральным элементам (які з цягам часу стане ўніверсальнай катэгорыяй мастацкага дыскурсу Гарэцкага), пісьменнік працягвае і ў рамане Віленскія камунары. Рэальная гістарычная падзея у Вільні 1919 г. (эпізод супрацьстаяння групы мясцовых камуністаў, якім на дапамогу ішло Чырвонае войска, з узброенымі палякамі - на той час гаспадарамі Вільні) фармальна з'яўляецца кульмінацыяй сюжэта ў рамане М. Гарэцкага Віленскія камунаpbl. У сюжэтнай цэласнасці рамана за гэтым эпізодам прачытваецца вельмі насычаны, алюзійна разгалінаваны, актуальны гістарычны падтэкст. М. Гарэцкі знаёміць чытача з гісторыяй беларускага руху ў Вільні, акцэнтуе ўвагу на звестках пра барацьбу за ўласную дзяржайнасць, за нацыянальныя правы беларусай сярод літойцаў, палякаў, яўрэяй. Гэтыя звесткі падаюцца мастаком праз наіўную свядомасць персанажаў, аднак прысутнасць аўтара ў тэксце робіць яго шматзначным, поліфанічным, адкрытым для адэкватнага, а не наіӱнага прачытання.

«Беларускі, нашаніўскі» настрой Вільні адчуваецца на працягу ўсяго рамана, і гэта пры тых умовах, што твор пісаўся падчас адбывання пісьменнікам тэрміну высылкі ў Вятку. Для прыкладу звернем увагу на апісанне «інфраструктуры» Вільні. Акрамя пэўнай колькасці крамаў, сталовак і майстэрняў у 1914 годзе там адкрыўся Беларускі клуб на Віленскай вуліцы, 29. Пазней, у 1915 годзе, расчыніў дзверы 
Рабочы клуб на Вароняй вуліцы. Гэтыя дзве ўстановы існавалі ў Вільні на самай справе, і работа вялася ў іх паралельна. У артыкулах А. Луцкевіча ёсць згадкі пра ix.

Так, захавалася «Рэзалюцыя паседжання Беларускага клюбу у Вільні 8 верасня 1917 г.», у якой адзначана, што «члены Беларускага Клюбу і запрошаныя госці, выслухаўшы на сходзе 8 верасня 1917 г. рэферат і прамовы аб беларускіх палітычных ідэалах і дамаганнях, выказваюць сваю салідарнасць $з$ рэзалюцыяй канферэнцыі беларускіх арганізацый у Вільні, апублікаванай у Універсале канферэнцыі, і далучаюць свой голас да жаданьня незалежнасьці і непадзельнасьці ўсіх Беларускіх і Літоўскіх зямель, ухадзіӱшых калісь у склад Вялікага Княства Літоўскага, у найцясьнейшай еднасьці з Курляндзіяй» [Луцкевіч 2009, 140]. Тэкст яшчэ адной рэзалюцыі змяшчае наступныя словы: «Сабраўшыеся 3 верасня 1917 года ў Беларускім Клюбе прадстаўнікі ўсіх кірункаў беларускага грамадства сталічнага месца Вільні, цьвёрда веручы, што набліжаючыйся мір прынясе незалежнасць для ўсяго Беларуска-Літоўскага краю, разьдзеленага цяпер на часьці ваенным фронтам, выказваюць сваё жаданьне, каб ужо ӱ часе вайны правы Беларускага народу ў межах нямецкай акупацыі былі забясьпечаны ў поўнай меры» [Луцкевіч 2009, 144].

Сходы і разнастайныя мерапрыемствы падобнага кшталту праводзіліся і ў Рабочым клубе, які у дакументах згадваецца як Работніцкі Клюб. Так, у «Рэзалюцыі мітынгу сацыялістычных і дэмакратычных арганізацыяу 16 верасня 1917 г.» паведамляецца: «Сабраўшыеся на мітынгу 16 верасня ў салі Работнічкага Клюбу прадстаўнікі сацыялістычных і дэмакратычных кругой літоўскай, беларускай, польскай і жыдоўскай нацыянальнасцей прынялі гэткую рэзалюцыю аб будучыні Літвы:

Сабраўшыеся кіруюцца глыбокім перакананьнем, што толькі дайшоўшы палітычнай самабытнасьці Літвы і збудаваўшы яе ӱнутранае жыцьцё на асновах праўдзівага дэмакратызму, можна падняць наш Край з упадку і забясьпечыць яму найлепшыя варункі дзеля развіцьця яго творчых сіл, падняцьця дабрабыту і поўнага здаволення культурна-нацыянальных патрэб усіх пражываючых у Літве нацыянальнасцей» [Луцкевіч 2009, 142].

3 дакументаў відаць, што работа ў клубах вялася сур'ёзная. М. Гарэцкі ж перадае атмасферу Беларускага клуба наўмысна несур'ёзна, вачыма героя-прасцяка, 3 іранічна-зніжанай інтанацыяй: «Там былі невялічкія канцэрцікі, спевы, а пасля - скокі і розныя гульні. Хадзілі туды $\ddot{y}$ большасці вучні з настаўніцкага інстытута і хіміка-тэхнічна- 
га вучылішча, розная служачая моладзь, дзяўчаты - дочкі дробных служачых і рабочых, а таксама дзяўчаты, што былі ў вёсках і працавалі у горадзе - хто хатняю прыслугаю, хто прачкаю, хто чым...» [Гарэцкі 1985, 192]. У такой манеры апавядае пра клуб галоўны герой рамана Мацей Мышка. Пісьменнік жа добра ведаў, што Вільня пачатку XX стагоддзя - цэнтр зараджэння нацыянальнага беларускага руху. Тут распачынала сваю дзейнасць «Наша ніва», сюды з'язджаліся дзясяткі беларусаў, каб падтрымаць нацыянальную ідэю. «Беларускае» заўсёды побач з Мацеем - невыпадкова ў гэты клуб прывёў яго дзядзька Туркевіч. Існуе вялікая верагоднасць таго, што прататыпам Туркевіча з рамана «Віленскія камунары» быў Язэп Туркевіч, прадстаўнік Беларускай работніцкай групы, паплечнік братой Луцкевічай у барацьбе за нацыянальнае раўнапраўе. Адным са сведчанняў на карысць гэтай думкі з'яўляюцца заўвагі самога аўтара, даведзеныя чытачу праз своеасаблівае пасярэдніцтва галоўнага героя: «Славу “шчырага беларуса", з ліку блізка знаёмых мне віленскіх рабочых, меў ужо тады дзядька Туркевіч, гэты наш “столяр з Пагулянкі". Ён, з аднаго боку, быў вядомы як рабочы-рэвалюцыянер яшчэ з 1905 года і быў свой чалавек у коле такіх маіх добрых знаёмых, як Ліцкевіч, Вяржбіцкі, Тарас, Мацяйковіч і іншыя ${ }^{1}$. А з другога боку, калі яны да беларускае мовы адносіліся безуважна, а некаторыя, як мой бацька, нават непрыхільна, дык Туркевіч заўсёды і ўсюды, нават на вуліцы, гаварыў па-беларуску, хоць і польскаю моваю валодаў дасканала, лепш, чым яны» [Гарэцкі 1985, 218-219].

Ды і выпадковыя аматары паскакаць у клубе насамрэч не выглядаюць такімі ўжо абыякавымі да ідэі, калі ӱзгадаць, як распачынала сваю працу Наша ніва. Так, у манаграфіi «Наша ніва і беларускі нацыянальны рух» А. Унучак заўважае: «Паступова невялічкае кола інтэлігенцыі, якая на самым пачатку складала рэдакцыю Haшай нівы, ператвараецца у цэлую плынь, дзе адначасова працуюць і выдатныя палітычныя і эканамічныя аглядальнікі, і паэты, і празаікі, а таксама вялікая колькасць людзей, якія да гэтага часу не мелі нічога агуль-

1 Подпісы Язэпа Туркевіча і Язэпа Ліцкевіча стаяць побач у шэрагу такіх дакументаў, як «Ліст Арганізацыйнага Камітэту дзеля скліканьня Беларускай Канфэрэнцыі ў Вільні» (1917), «Зварот да начальніка адміністрацыі акругі Літвы» (1917), «У Галоўную камісію Райхстагу $\ddot{y}$ Берліне» (1917), што паказвае іх аднолькавую палітычную пазіцыю ў дачыненні да беларускага пытання. Так, яны шчыра віталі пастанову Галоўнай Камісіі Рэйхстагу аб правядзенні ў жыццё у час першай сусветнай вайны самаўпраўлення беларуска-літойска-латышскіх зямель акупацыі на аснове давер'я да прадстаўнікоў усіх нацыянальнасцей краю. 
нага з беларускім рухам - вясковьля настаўнікі, пісарь, гарадскія рабочьля, сяляне $і$ беларусьи, якія апьнуліся за межамі Бацькаўшчьны» [Унучак 2008, 36]. Таму невыпадкова у рамане Віленскія камунары нават Мацей Мышка «напісаў адзін вершык пад Купалу» і паслаў яго у рэдакцыю, аднак запрашэння не атрымаў: тым самым М. Гарэцкі падкрэслівае, што не так і проста было трапіць на старонкі гэтай газеты.

У гэтым клубе таксама гучала беларуская мова, чыталіся вершы Цёткі, Гапон Дуніна-Марцінкевіча, быў драмкружок, хор, аркестр. Потым нават арганізавалі свой кааператыў, адчынілі бібліятэку. Нягледзячы на забаўную манеру аповеду, ужо традыцыйна замацаваную за Мышкам, названыя М. Гарэцкім факты адпавядаюць гістарычнай прайдзе.

Задачай беларускай інтэлігенцыі была барацьба з невуцтвам сярод сялян, бо толькі пераадолейшы гэтую праблему можна было далучыць беларускае сялянства да ідэі нацыянальнага адраджэння, абудзіць яго свядомасць. Гісторыкі адзначаюць: «Нашу ніву цікавіў выхад сялян 3 "цямноты", непісьменнасці, далучэнне іх да адукаваных пластоў насельніцтва, да “ідэалагічнай Айчыны", г.зн. да мыслення нацыянальнымі катэгорыямі. Таму $\breve{y}$ газеце актыўна прапагандавалася справа адкрыцця бібліятэк у вёсках...» [Унучак 2008, 48]. Вільня на той час ужо стала цэнтрам нацыянальнага беларускага руху, і М. Гарэцкаму ўдалося ў пэўнай ступені абысці ідэалагічную цэнзуру 1930-х гг., перанесці своеасаблівы нашаніўскі, адраджэнцкі настрой на старонкі рамана «Віленскія камунары».

«Беларускі, нашаніўскі» настрой Вільні адчуваецца на працягу уссяго рамана. М. Гарэцкі па-майстэрску хавае «сакральнае», «раскідваючы» значныя для беларускага руху пачатку ХХ стагоддзя імёны па старонках твора.

Так, Мышка на хвіліну забягае ў каўбасню Мэнке, працуе, не маючы клопату, на лесапільні графа Тышкевіча. На першы погляд, гэта проста раманныя топасы (крамы, лесапільні), месцы, дзе адбываюцца тыя ці іншыя падзеі твора. Аднак, калі звярнуцца да гісторыі, то павярхойная самадастатковасць ва ўспрыняцці мастацкага тэксту знікне. Вядома, што Ю. Мэнке была нарачонай І. Луцкевіча і прыйшла ў беларускі рух пад яго ўплывам. Цётка ж навучалася у Віленскай гімназіі разам са старэйшай сястрой Ю. Мэнке. Каб падтрымліваць выданне Нашай нівыл, не змяншаючы колькасці асобнікаў, неабходна было бесперапыннае фінансаванне, гэтым пытаннем актыўна займаўся І. Луцкевіч. Ёсць звесткі пра супрацоўніцтва Луцкевіча з гра- 
фам Тышкевічам пры продажы маёнтка ў Мінскай губерніі. [Унучак 2008, 40-41].

Такім чынам, вышэйназваныя асобы спрыялі развіццю нацыянальнага руху ӱ Вільні ў рэальным жыцці, згаданыя ж у рамане Віленскія камунары імёны з'яўляюцца прэцэдэнтнымі ӱ беларускім культурным кантэксце. Гэта своеасаблівая падказка чытачу, напамін пра тое, што твор патрабуе глыбокага прачытання, асэнсавання, што адпаведнасць падзей гістарычнай праўдзе - першы крок да спасціжэння сутнасці твора.

А зараз звернемся да паняцця "спосабу мыслення фактамі", характэрнага для канкрэтнай асобы ў канкрэтны гістарычны перыяд пры канкрэтных абставінах. Відавочна, што М. Гарэцкі стварыў наватарскую для беларускага пісьменства ўскладненую апавядальную форму, якая дазволіла яму выявіць у творы глыбокае разуменне рэчаіснасці, паказаць тую прыхаваную праўду, пра якую ў святле тагачаснай савецкай ідэалогіі нельга было казаць адкрыта.

Нельга сказаць, што М. Гарэцкі працуе у эстэтыцы "дакумента", факт у яго творы прысутнічае імпліцытна, і суровасць, пэўная прадвызначанасць “спосабу мыслення фактамі" у тым, што пісьменнік не можа мысліць у сваёй сітуацыі іншым чынам, бо рэальна ацэньвае яе. "Быць рацыянальным - значыць мысліць, а для чалавека, які плануе здзейсніць які-небудзь учынак, самае галоўнае прадумаць сітуацыю, у якой ён знаходзіцца. У дачыненні да гэтай сітуацыі ён зусім не вольны. Яна з'яўляецца тым, што яна ёсць, і ні ён, ні хто-небудзь іншы не здолеюць яе змяніць", - пісаў Р. Дж. Колінгвуд [Коллингвуд 1980, 303]. Дык вось як чалавек з рацыянальным розумам, М. Гарэцкі вымушаны адмовіцца ад прамой манеры пісьма, і праз дэманстрацыю афіцыйна дазволенай сітуацыі прыхавана распавядае пра "забароненую рэчаіснасць".

Такім чынам, у нашых разважаннях над функцыянальнай роляй факта $\ddot{\mathrm{y}}$ мастацкім дыскурсе М. Гарэцкага можна зрабіць наступныя высновы: факт як літаратурны феномен прысутнічае узжо ў ранніх творах Гарэцкага. Беручы свой пачатак у пубіцыстыцы, рэальны факт становіцца сродкам мастацкага выражэння аўтарскага светапогляду. Факт трансфармуецца у сюжэтастваральны элемент пры дапамозе драматычнага напружання калізіі, антытэзы і аўтарскага ўмення разгледзець у прадмеце палярнасць значэнняў. У рамане Віленскія камунары пісьменнік прыкрывае рэальны факт фактам мастацкім, так званым фактам-трансфарматам, робячы пры гэтым рэальны факт тым вобразам, які, як адбітак пісьменніцкага светапогляду, патрабуе 
мастацкай апрацойкі. Менавіта праз супастаўленне факта рэальнага з фактам-тансфарматам мы набываем магчымасць адчуць рэальны голас пісьменніка ӱ творы.

\section{Літаратура}

Garadnìckì Â., 2018, Paabodva baki tèkstu: uvasablenni, intèrprètacyì, Мìнск. [Гарадніцкі Я., 2018, Па абодва бакі тэксту: увасабленні, інтэрпрэтачыі, Мінск.]

Mestergazi E., 2007, Literatura non-fikšn / non-fiction: Èksperimental'nâ̂ ènciklopedii. Russkâa versiâ, Moskva. [Местергази Е., 2007, Лumepamyра нон-фикшн / non-fiction: Экспериментальная энциклопедия. Русская версия, Москва.]

Sin'kova L., Basova A., 2009, Stanovleniedokumental'no-hudožestvennogo žanra $v$ žurnalistike Svetlany Aleksievič, "Vesnìk Belaruskaga dzâržaǔnaga unìversittèta" seryâ 4, s. 93-96. [Синькова Л., Басова А., 2009, Становление документально-художественного жанра в журналистике Светланьи Алексиевич, "Веснік Беларускага дзяржаўнага універсітэта", серыя 4, с. 93-96.]

Gubskaâ V., 2016, Klasika HH stagoddzâa: pryhavanyâtaâmnìcy ramana "Vilenskîa kamunary" M. Garèckaga, Mìnsk. [Губская В., 2016, Класіка XX стагоддзя: прыхаваныя таямніцы рамана "Віленскія камунары" М. Гарэцкага, Мінск.]

Naša nìva, 2009, Štotydnëvaâ gazeta: Faksimil'nae vydanne, Vyp. 5 (1912-1915, 1920 gg.), Mìnsk. [Наша ніва, 2009, Штотьлнёвая газета: Факсімільнае вьъданне, Вып. 5 (1912-1915, 1920 гг., Мінск.]

Garèckì M., 1985, Atruta, Mìnsk. [Гарэцкі М., 1985, Атрута, Мінск.]

Luckevič A., 2009, Barac'ba za vyzvalenne, Belastok. [Луцкевіч А., 2009, Бараиьба за вызваленне, Беласток.]

Garèckì M., 1985, Vìlenskiâ kamunary, Mìnsk. [Гарэцкі M., 1985, Віленскія камунары, Мінск.]

Unučak A., 2008, "Naša niva" i belaruski nacyânal'ny ruh (1906-1915gg.), Mìnsk. [Унучак А., 2008, "Наша ніва" $i$ беларускі наџьянальны рух (1906-1915 г2.), Мінск.]

Kollingvud R., 1980, Ideâ istorii. Avtobiografiâ, Moskva. [Коллингвуд P., 1980, Идея истории. Автобиография, Москва.] 


\section{DOCUMENTED FACT AS A WAY OF FICTION}

\section{S U M M A R Y}

Key words: documented fact, fiction, topas, non-fiction, literature of fact

This article is an attempt to answer the question: what is the specificity of the real existence, documented facts in a literary context. It examines the role of historical fact in the literature. It is alleged that the phenomenon of historical fact, included in the text, functions as an artistic image, that expanding the possibilities of the writer. That is why there is a need to study the fact with an additional of the image as well as understanding these facts as a means of artistic expression for a particular person in a particular historical period under specific circumstances. 